\title{
The priest doctors
}

\author{
Lesley Smith
}

\section{Priest doctors}

As the stream of monks left their foundations at the dissolution of the monasteries in the mid-16th century, the society that surrounded them was profoundly affected. While some fought dramatically against closure - even losing their lives - the vast majority of monks went quietly, with pensions, into the sunset. No matter how welcome the Reformation was to many, for hundreds of years these monasteries had provided work, some education, shelter, legal systems and medical support.

The idea of the healing monk is not just lodged in the mythical 12th century Brother Caedfael of Shrewsbury. In fact, a vast majority of the early doctors were also priests or monks. There are many logical reasons for this. Priests were educated men; they could read the works of the Greek medical philosophers and put their works into practice. The bible is dotted with examples of Christ healing the sick and lame, so they were following in His footsteps. Another good reason why priests were considered suitable to be doctors was their high moral and spiritual standing, which gained immediate respect and trust in the community. One might call it a sort of 'body and soul' approach.

\section{Medical schools}

Medical schools sprang up. The first was in Salerno in Italy, which was well established by the 10th century and became revered as the medical capital of Europe. In the early 13th century the cathedral masters began to receive legal corporate recognition as centres where medicine could be studied. Universities started to have specialist departments for the study of medicine, the more famous ones being Padua and Bologna in Italy and Basle in Switzerland. Montpellier in France was formed in about 1300 and by the end of the 16th century was recognised as the leading medical school in Europe, overtaking even Salerno.

Studies for doctors began with the Liberal Arts and included rhetoric, astronomy, mathematics and - oddly music. After the degree of Master of Arts had been gained following the requisite 7 years' study, candidates could enter a Faculty of Medicine, very often in a foreign university.

Montpellier provided the model for learning that was copied for centuries all over Europe. The first lecture of the day was from 5.00 am until 10.00 am followed by a communal dinner at $10.30 \mathrm{am}$. Lectures then began again at $1.00 \mathrm{pm}$ and continued until $5.00 \mathrm{pm}$.

Although Oxford and Cambridge in the UK already had well-established departments of medicine, by the time Henry VIII was on the throne, medical teaching in Oxford and Cambridge had fallen to a very low level. As a result, many English postgraduates went abroad for their MD qualification, which could take a further 4 years. Experienced physicians passed on their skills in the art of diagnosis and how to examine patients. Medical school

\section{J Fam Plann Reprod Health Care 2007; 33(2): 131-132}

Tutbury Castle, Tutbury, UK

Lesley Smith, Curator

Correspondence to: Lesley Smith, Tutbury Castle, Tutbury, Staffordshire DE13 9JF, UK. E-mail: info@tutburycastle.com candidates would have approached their finals with even more trepidation than the students of today. Not only would they have to publish their thesis, they would also have to sit in front of panels of regents, often for days on end, repelling vigorous challenges about their work. No wonder a qualified MD was so highly prized with his new robes, square cap, ring and girdle of gold - they had certainly earned all their honours.

The College of Physicians was established in 1518 by Henry VIII and took clear steps in establishing ethical principles and making individual professionals responsible for their actions. The college encouraged objectivity, a little science and was described by one observer as "That College of learned and grave men".

\section{Surgeons}

The profession of surgeon was founded from a different root. In the 13th century, Pope Innocent III decreed that no priest could shed any blood, not even in the process of healing. After this, priest doctors were usually accompanied by a lay brother who would, under direction, carry out minor surgery - or for the unlucky - major surgery. Surgeons were described as the 'un-Latined' men, and were viewed as undereducated. It would be centuries before surgeons reached the social status of their colleagues, the doctors. Physicians ruled supreme and were usually very rich indeed.

Membership of the Fellowship of Surgeons and Barbers Company in 1540 offered members a licence to practise basic examinations and was the start of formal professional recognition. Barber surgeons were viewed as technical craftsmen, even artisans. Amongst the amateur ranks of quacks (the polite term being Empirics), those at the top could be licensed as medical practitioners. Some of these were women who were not midwives, as they worked under a different licence.

\section{Medicine and magic}

Spirituality had always played a major part in healing, and also in 'pre-Christian' society. The mysteries of outside spiritual intervention and the positive results of confidence and faith are still seen and recognised by the medical profession today.

By the end of the Tudor period, it was not possible to see a clear distinction between medicine and magic, alchemy and science or astronomy and astrology. All doctors would dabble a little in what we would today view as the occult. White, natural magic founded in an ancient past was mixed with contemporary Christian views. Black magic, including the calling of demons or even Satan, would not be touched by any doctor of good reputation.

Sorcerers practised within the highest levels of society. Elizabeth I had her own magician, Dr John Dee, and leaned on him heavily for advice about key issues, including her own coronation date. The British Museum has a black mirror through which Dee 'spoke' to the angels. There is a respectable body of opinion that supports the view that Dee was not so much a sorcerer as a real renaissance man, fascinated with everything and experimenting endlessly. This hunger for knowledge would lead us to the anatomists, chemists and 'real' scientists.

While the spirituality of the priest doctor played such an important part in healing, empiric medical practitioners 


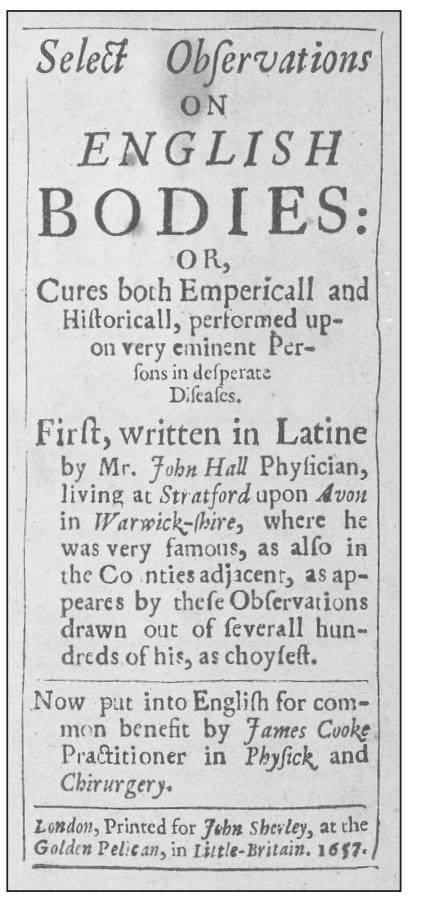

Figure 1 Title page of the first edition of John Hall's Select Observations on English Bodies (1657). Figure reproduced with permission. (C) The Shakespeare Birthplace Trust

would include their own form of mystical input into the process (Figure 1). It is easy to see why it was not a far distance from the cry of 'witch'. There would be particular interest in accusing a competitor of witchcraft, for there is no doubt that competition was fierce for the available lucrative financial rewards. We should also appreciate that some illiterate 'cunning women' who were the lowest form of 'quack' were actually competent herbalists, possessing skills passed down from generation to generation. Without a truly effective matria medica one can see the power a successful wise woman might hold over a whole community, including the merchant classes. The quacks would be a splinter in the eye for a university educated doctor and even more so for an ambitious licensed medical practitioner, whose potential market she could most affect. If her medicines and creams were seen to be effective, some might consider her a witch. It would be supposed that she must have called upon dark assistance, as surely an uneducated person could not be more successful than a 'Latined' one?

I don't think it would be appropriate, however, to consider all witches to be little old ladies making efficacious cough medicines. Some of these 'wise' women were very sinister indeed, being involved in extortion, abortion, murder and blackmail. There are extant Court papers that demonstrate clear and, I am afraid, sometimes highly amusing fraud.

The misogynistic and paranoiac persecutions by James VI of Scotland (James I of England) gave many with a vested interest a chance to get rid of some of these cunning women by burning them at the stake. (In England these individuals were usually hung.) Ironically, the birth of James VI in Edinburgh Castle in 1566 proved so slow and potentially dangerous for his mother, Mary Queen of Scots, that a local witch was brought to the chamber to assist. She did so by casting the pains of Mary Stuart onto a witnessing Earl who showed willing by lying on the bed by Her Grace and rolling around in agony. This event is well documented.

At the deathbed in February 1685 of Mary's great grandson, Charles II, witchcraft was still firmly a medical option. Records of his treatment show that hot stones, cold stones, mercury on the gums, bleeding, leeching and a range of cupping were not enough. In desperation, "spirit

of skull" was brought to Charles' chamber: a human skull held in spirit, which was to be drunk by His Majesty. The Merrie Monarch apologised for taking so long to die, though in fact it is remarkable that he lasted so long. It is a sobering thought that all these events occurred in the time of Wren, Pepys, Ashmole and Murray.

\section{Future articles}

Readers may be interested to note that the next article in the series will be on 'Monstrous births and how to avoid them'.

\section{Acknowledgements}

The author would like to thank the following individuals for their help and advice: Dr R Arnott, Director of the Centre for the History of Medicine, University of Birmingham Medical School, Birmingham and Dr G Williams, Curator of the British Museum, London, UK.

The author also acknowledges the assistance provided by the Shakespeare Centre Library, Stratford-upon-Avon, UK in sourcing and supplying the illustration.

\section{Bibliography}

1 Galen. On the Natural Facilities. Translated from Greek to English by John Arthur Brock. Bury St Edmunds, UK: St Edmundsbury Press Ltd, 1916.

2 Unknown author. The Rose Garden of Pregnant Women and Midwives. Strasbourg publisher, 1530. Translated from Der Swangern Frawen und Hebammen Rosengarten.

3 Jonas, Richard. The Birth of Mankind. Unknown publisher, 1540. Translated from De Patu Hominus.

4 Copeman WSC. Doctors and Disease in Tudor Times. London, UK: Dawsons of Pall Mall, 1960

5 Lane, Joan. John Hall and His Patients. Stratford-upon-Avon, UK: The Shakespeare Birthplace Trust, 1996

6 Hamilton, David. The Healers. Edinburgh, UK: Canongate Publishing, 1981.

About the author

Lesley Smith is an Elizabethan historian, currently studying for the degree of MPhil in the History of Medicine at Birmingham University Medical School. She has appeared in 32 television programmes including Tony Robinson's The Worst Jobs in History, and is currently working on an eight-part 1-hour major series on the Private Lives of Women. Lesley is also well known as a public speaker.

\section{Author's note}

For the readers of this journal who have expressed an interest in finding out more about the study of the history of medicine I felt it appropriate to provide a brief outline as follows.

Medical history as a subject in its own right is relatively new, although it has featured in many curricula from English literature to science subjects. I have found a paper discussing the gynaecology of Mary Queen of Scots published by a doctor less than a century after her death.

Before the 1960s, it is thought there were fewer than ten professional medical historians in the UK. Today there are about forty, of whom the majority study the perception in society of doctors and medicine, rather than clinical issues, which is my own area of interest. It would seem that medical historians are rather a rare breed!

Here in Britain, there are a few eminent medical historians, such as my tutor, Dr Bob Arnott, who is Director of the Centre for the History of Medicine of the University of Birmingham Medical School. He is also the Regional Sub-Dean, for the Midlands, of the Royal Society of Medicine. Dr Arnott is a world authority on early Greek medicine and he too addresses clinical issues.

It is assumed that most medical historians are general practitioners or specialists but their backgrounds are a little broader than one might think. Bob Arnott trained originally as an archaeologist. I am very much a 16th century historian. Others are chemists, biochemists or, in one case, a composer!

It is a thrilling area of study and endlessly fascinating to seek and hopefully find evidence that may refute or confirm our current understanding of the past. Medical historians have to be prepared to be detectives and to work with a range of other experts such as historians, classicists, chemists and gynaecologists. I am most fortunate in having the support of a range of specialists in other fields who have helped and supported my work over the years, and for which I am profoundly grateful.

For readers of this publication who might like to find out more, even if only for guidance of the type of background material to read, I would be delighted to help. 